\title{
O significado da História
}

Frederick Jackson TURNER ${ }^{1}$

Tradução e Apresentação: Arthur Lima de AVILA²

RESUMO: Frederick Jackson Turner (1861-1932) foi um dos mais importantes historiadores norteamericanos do século XX. Através de sua atuação na academia, institucionalizou-se o estudo da chamada "história-problema", em que a disciplina deveria fornecer a compreensão do presente através da análise do passado. Defensor do caráter presentista da História e de um relativismo moderado, Turner estabeleceu vários dos pressupostos que se tornariam padrões nas universidades dos Estados Unidos, como o estudo das "forças invisíveis" que ritmam e determinam o processo histórico e da grande massa de seres humanos anônimos que ajudaram a construir a democracia em terras americanas.

PALAVRAS-CHAVE: Frederick Jackson Turner; historiografia norte-americana; presentismo.

\section{APRESENTAÇÃO}

0 historiador norte-americano Frederick Jackson Turner (1861-1932) é considerado o grande pai da historiografia moderna nos Estados Unidos. $M$ ais conhecido por sua famosa frontier thesis, que postulava a centralidade do processo de expansão para o desenvolvimento da democracia em terras americanas, ele foi um dos primeiros historiadores a insistir no desvelamento dos fatores econômicos e sociais que ritmavam a evolução das sociedades. Durante toda a sua vida profissional, que se estendeu 
de 1890 a 1924, Turner foi um entusiasmado defensor da função social da disciplina e da necessidade de se estudar a História para uma melhor compreensão do presente.

O historiador nasceu em uma pequena cidade de Wisconsin, em 14 de novembro de 1861, e realizou a maior parte de sua formação acadêmica na Universidade Estadual, localizada em Madison, capital do Estado. No biênio 1888-1889, Turner completou seus estudos na prestigiosa Universidade Johns Hopkins, em Baltimore, no que era o principal centro de formação de cientistas sociais do período. Em 1890, o jovem retornou a M adison para assumir um posto como professor, cargo que ocuparia até 1910, quando, no auge da fama, foi convidado a assumir uma cátedra em Harvard. Turner se aposentou em 1924 e faleceu na cidade de San Marino, na Califórnia, em 1932. Quando de sua morte, ele era considerado o maior historiador norte-americano e um dos principais pensadores do país. $^{3}$

O sucesso de Turner derivou em grande medida de sua atuação decisiva no processo de institucionalização da profissão nos Estados Unidos (e da conseqüente mudança dos parâmetros de atuação dos historiadores) e da ampla ressonância social encontrada por sua frontier thesis. Esta teoria conseguiu, de maneira ímpar, não só explicar o desenvolvimento histórico dos Estados Unidos em uma linguagem científica, mas também criou um verdadeiro épico para a origem da nação, transferindo a ação dos grandes personagens históricos para a os milhares de anônimos que ajudaram a construir a democracia americana.

Até fins do século XIX, a historiografia norteamericana estava pautada por dois eixos de atuação: a história "romântica", realizada por pesquisadores amadores, e a chamada germ theory ou "teoria 
genética", defendida pelos poucos historiadores profissionais de então. A historiografia romântica, cujo maior expoente foi Francis Parkman, enfatizava a narração e o aspecto literário da história em detrimento de uma linguagem, ou mesmo de uma metodologia mais científica. Os românticos defendiam a historia magistra vitae, enfatizando seu caráter pedagógico. ${ }^{4}$ á a teoria genética enfatizava a continuidade da democracia norte-americana, cujas origens podiam ser remontadas às florestas da Germânia medieval. Os genes germânicos dos norteamericanos explicariam, portanto, o nascimento de suas instituições democráticas. Segundo estes historiadores, a história dos Estados U nidos estava unida à Europa de maneira perene. ${ }^{5}$

Turner e seus discípulos tiveram uma atuação decisiva para a reversão deste quadro. Em 18930 então jovem historiador lançou ao mundo seu mais famoso escrito, "The Significance of the Frontier in American History" ( "O Significado da Fronteira na História Americana"), onde estabelecia as bases da sua frontier thesis. Em linhas gerais, ele afirmava uma história autóctone para a América. Segundo ele, a fronteira havia sido 0 grande motor do desenvolvimento social norte-americano e 0 principal motivo de sua excepcionalidade diante das outras nações da Terra. Os diversos pioneiros, homens e mulheres, eram os verdadeiros founding fathers da nação. $M$ ais do que isso, ele abandonava a idéia de uma fronteira fixa, como a européia, e introduzia a noção de uma fronteira processual, isto é, em constante movimento, do Atlântico ao Pacífico. Neste sentido, ele introduzia o estudo dos diversos elementos econômicos e sociais que haviam sido determinantes para o movimento expansionista. Eram estas "forças invisíveis" que agiam sob a superfície dos acontecimentos políticos e que deviam 
ser estudadas para uma melhor compreensão da história estadunidense. ${ }^{6}$

Durante as duas décadas seguintes, Turner foi desenvolvendo esta hipótese de trabalho em outros textos, acadêmicos ou não, tendo um maior destaque os seguintes: "The Problem of the West" ("O Problema do Oeste"), de 1896; "Contributions of the West to American Democracy ("Contribuições do Oeste para a Democracia Americana"), de 1903; ${ }^{7}$ e "Social Forces in American History" ("Forças Sociais na História Americana"), de 1910. ${ }^{8}$ Todos estes escritos possuíam algo em comum, para além da frontier thesis: eles buscavam compreender 0 passado a partir de eventos do presente, conectando a História aos problemas sociais de seu tempo, fossem eles o fim da fronteira de assentamento, a eclosão dos diversos movimentos populistas do Oeste ou a transformação dos Estados Unidos em uma potência hemisférica.

Concomitante à ampla exposição de sua teoria, e como resultado desta, Turner foi arregimentando um crescente grupo de jovens estudantes ao seu redor. Na primeira década do século XX, a Universidade Estadual do Wisconsin já era um dos principais pólos de formação de novos historiadores e a "Escola de Wisconsin", com sua ênfase nos aspectos socioeconômicos, era a mais importante referência para a historiografia norte-americana. Tal façanha é creditada ao intenso trabalho de Turner como orientador, chefe de departamento e professor. ${ }^{9}$ Para comprovar sua importância, basta dar uma olhada na sua lista de orientandos imediatos. Dentre os diversos nomes, encontramos alguns dos mais importantes historiadores americanos do século XX, como Carl Becker, Merle Curti e Arthur Schlesinger, Sr.. M esmo após sua ida a Harvard, o Departamento de História de Madison 
continuou sendo um dos mais importantes dos Estados Unidos. ${ }^{10}$

A importância da "Escola de Wisconsin" foi tamanha, que mesmo universidades consagradas como Stanford e Yale adaptaram seus departamentos de história aos parâmetros estabelecidos por Turner em Madison. Em 1910, ano em que o historiador foi para $\mathrm{H}$ arvard, a frontier thesis já era aceita como a principal explicação histórica nos Estados Unidos, sendo utilizada não só na academia, mas também fora dela. Um dos motivos para esta ampla ressonância era a sua capacidade de falar sobre a maioria dos norte-americanos, construindo uma narrativa que superava as divergências sociais e regionais para a criação de uma visão harmônica da história estadunidense, que explicava não só 0 passado da nação, mas também Ihe fornecia apontamentos para o futuro, no que Richard Slotkin chamou de um "paradigma de ação", através da constatação da inevitabilidade da expansão das fronteiras dos Estados Unidos - no continente e fora dele. ${ }^{11}$

Frontier thesis enfrentou uma série de críticas após a morte de seu autor. Durante as décadas de 30 e 40 muitos historiadores a descartaram como sendo ineficiente para uma explicação global da história norte-americana, apontando algumas de suas insuficiências teóricas e inconsistências empíricas. ${ }^{12}$ A explicação de Turner foi recuperada durante as décadas de 50 e 60, principalmente pela historiografia do Oeste e por historiadores funcionalistas e economicistas, ${ }^{13}$ mas com 0 advento da N ova H istória Social, a partir de fins dos anos 60 , ela caiu em descrédito uma vez mais. 0 surgimento da chamada New Western History, em meados dos anos 80, foi também decisivo para que a frontier thesis fosse descartada como uma explicação demasiadamente otimista e autoglorificadora da 
história da América. ${ }^{14}$ Ainda assim, quando do centenário de lançamento de "The Significance of the Frontier in American History", muitos jornais e revistas celebraram o legado turneriano e muitos acadêmicos saíram em defesa daquele seu distante colega. ${ }^{15}$ Mesmo seus críticos mais ferrenhos admitiram que, cem anos após sua primeira exposição, o fantasma de Turner continuava pairando sobre os departamentos de história de todos os Estados Unidos. Aliás, alguns de seus opositores mais ferrenhos acabariam por voltar atrás em algumas de suas objeções iniciais e reconheceriam o pioneirismo de certas afirmações do professor de Harvard. ${ }^{16}$

$M$ ais do que a elaboração da frontier thesis, o legado deTurner pode ser encontrado na introdução de conceitos então revolucionários para 0 pensamento histórico nos Estados Unidos, como a noção de "forças invisíveis", o presentismo e um moderado relativismo. Durante toda a sua vida, 0 historiador advertiu seus historiadores a estudarem os mais diversos aspectos do processo histórico, já que, segundo ele, não existia uma única chave para a compreensão da História, mas várias. ${ }^{17}$ Além disso, ele batalhou para um maior entendimento entre as diversas Ciências Sociais ${ }^{18}$ e advertiu para as explicações que se propunham "definitivas", já que a História estava em constante mutação. 0 presente recriava o passado de acordo com suas próprias necessidades. Os homens estavam sempre reescrevendo sua própria história.

"The Significance of History" ("O Significado da História"), escrito em 1891, originou-se de uma palestra que Turner proferiu a um grupo de professores do ensino primário e secundário do Estado de Wisconsin e constitui-se como seu único texto mais reflexivo acerca do métier e da utilidade social da História. Embora não tenha alcançado a 
notoriedade de seus escritos posteriores, ele é, sem dúvida, um de seus ensaios mais importantes e uma verdadeira referência para estudo da historiografia norte-americana dos séculos XIX eXX. N ele, o então jovem historiador explicava aos seus colegas as diversas utilidades práticas da disciplina e forçava-os a uma reflexão sobre seu próprio lugar no andar da História. Mas mais do que uma mera exposição de seus pressupostos teóricos, o texto é uma verdadeira profissão de fé de um historiador que sempre se esforçou em aproximar a disciplina dos problemas dos homens comuns, cujas preocupações não parecem assim tão distantes daquelas dos dias de hoje. Por isso, e para além de todos os seus defeitos, - legado turneriano merece ser constantemente revisitado por todos aqueles que, assim como Turner, admiram a beleza e a complexidade de Clio e compreendem que a História está, sim, em eterna construção. 


\section{O SIGNIFICADO DA HISTÓRIA}

As concepções sobre a história têm sido tão numerosas quanto os homens que a escreveram. Para Agustine Birell, a história é um espetáculo; ela existe para satisfazer a nossa curiosidade. Sob o toque do artista literário, o passado torna-se revivido. 0 historiador agita seu cetro como um outro Prospero, e as ruas vazias de Palmira ecoam com os sons dos artesãos, guerreiro luta contra guerreiro, torres arruinadas se erguem magicamente e a rica vida de gerações há muito passadas renasce nas páginas de um livro. A narração artística dos eventos passados - este é o ideal daqueles que vêem a história como literatura. A este grupo pertencem os literatos românticos que lutam para conceder à história as cores e a ação dramática da ficção, que não hesitam em pintar um personagem diferente daquilo que ele realmente foi, que dão vivacidade aos fatos brutos, que criam situações impressionantes, que, resumindo, lutam para repetir o sucesso de Walter Scott. É sobre este tipo de historiador que fala Freeman:

o melhor estilo, as mais belas metáforas e as frases mais bonitas das línguas estrangeiras seriam jogadas fora se eles estivessem devotados a provar que qualquer um dos dois lados de um triângulo nem sempre é maior do que o terceiro. Quando eles estão interessados em provar que um homem cortou a cabeça de sua mulher em um dia e casou com sua empregada na outra manhã, pelo amor de sua pátria, eles tornam este paradoxo crível.

É sobre o leitor deste tipo de história que escreve Seeley: 
para ele, como num milagre, os debates parlamentares sempre são vívidos e os funcionários públicos são sempre homens interessantes e fortes. Não há nada que o faça lembrar do livro escolar ou do livro das leis, nada comum ou prosaico; mas ele estará como se num teatro e observará o esplêndido cenário. Ele nunca será chamado ao estudo ou ao julgamento, apenas à imaginação e ao prazer. Suas reflexões serão exatamente aquelas de um leitor de romances; ele perguntará: Este personagem está bem caracterizado? Isto é realmente interessante? 0 desenrolar da história é factível?

Mas mesmo com todas estas críticas, nós podemos admitir que este é um estilo interessante e que não deve ser condenado, contanto que sua meta seja a verdade do conteúdo, e não a vivacidade do estilo. $M$ as, considerando que um homem possa ser possuidor de um bom estilo livre de devaneios, seja por um impulso artístico ou por causa de um partido, ainda assim permanecem diferenças quanto à meta e ao método da história. Para toda uma escola de escritores, dentre eles alguns dos maiores historiadores de nosso tempo, a história é o estudo da política, isto é, política no significado dado por Aristóteles, ou seja, tudo aquilo que se refere à atividade do Estado. "A história é a política passada e a política é a história presente", diz o grande autor da "Norman Conquest" ("A Conquista Normanda"). M aurenbrecher de Leipzig afirma em um tom parecido: "A flor dos estudos históricos é a história política"; e Lorenz de Jena confirma: "O campo apropriado da investigação histórica, no sentido literal da expressão, é a política". Diz Seeley: "O historiador moderno trabalha com a mesma tarefa de Aristóteles em sua 'Política'". "O estudo da história não é uma mera narrativa, sendo também um estudo teórico." "Estudar a história é estudar 
problemas." E assim um grande número de profundos investigadores, com um método verdadeiramente científico, explicou a evolução das instituições políticas, estudando-as como um biólogo estuda as sementes, as flores e os frutos. 0 resultado deste trabalho pode ser visto em trabalhos monumentais como os de W aitz sobre as instituições alemãs, de Stubbs sobre a história constitucional inglesa, e o de $M$ aine sobre as antigas instituições.

Existe um outro grupo de historiadores para quem a história é 0 estudo do crescimento econômico de um povo, buscando demonstrar que a propriedade, a distribuição de riquezas e as condições sociais de um povo são os fatores determinantes a serem estudados. Tendo transformado a economia política ortodoxa em método histórico, esta escola, que tem Roscher como pioneiro, está agora reescrevendo a história sob um ponto de vista econômico. Talvez a melhor expressão inglesa desta escola seja encontrada em "Economic Interpretation of History" ("Interpretação Econômica da História"), de Thorold Rogers. Ele afirma, com razão, que "na maior parte das vezes, a causa dos grandes eventos políticos e sociais é econômica". Como me parece tão importante este ponto fundamental, gostaria de citar diretamente as afirmações do Sr. Rogers sobre este novo método histórico:

N os séculos doze e treze existiam numerosas rotas dos mercados do Hindustão para os mercados ocidentais, para a condução daquele produto oriental tão desejado como condimento por nossos antepassados. Os principais portos pelos quais este produto era transportado eram Selêucia, no Cáspio, Trebizonda, no mar Negro, e Alexandria. Nestes portos, 0 produto era coletado principalmente por mercadores venezianos ou 
genoveses, e transportado para 0 alto Reno e 0 Danúbio. Aqui estava uma fonte de grande riqueza para as cidades da rota, de Ratisbona e Nuremberg a Bruxelas e Antuérpia. A corrente comercial não era tão grande ou profunda, mas era singularmente fértil, e qualquer um que conheça um pouco de história sabe quão importantes estas cidades eram na Idade M édia. Com o curso do tempo, todas estas rotas foram bloqueadas pelos selvagens que desolaram a Ásia central, com exceção de uma. Portanto, era necessária para estes mercados ocidentais a descoberta de uma rota marítima para as Índias. Todo o comércio oriental dependia da rota egípcia, e mesmo esta se encontrava ameaçada. 0 começo desta descoberta foi obra de um príncipe português. A expedição de Colombo foi uma tentativa de descobrir uma rota ocidental para as Índias. Por uma curiosa coincidência, se contornou o Cabo e se descobriu o Novo Mundo de maneira quase simultânea.

Estas descobertas vieram em boa hora. Selim I (1512-1520), sultão da Turquia, conquistou a M esopotâmia e as cidades sagradas da Arábia e anexou o Egito durante seu curto reinado. Esta conquista bloqueou a única rota remanescente conhecida pelo Velho M undo. As manufaturas de Alexandria foram rapidamente destruídas. O Egito cessou de ser uma estrada para o H industão. Eu descobri que alguma causa não suspeitada deveria estar por trás do repentino aumento dos preços dos produtos orientais no final do primeiro quarto do século dezesseis e que deveria ser resultado da conquista do Egito. 0 rio comercial havia secado rapidamente. As cidades que prosperaram ao seu redor foram gradualmente arruinadas, pelo menos no que diz respeito a esta fonte de sua 
opulência, e o comércio com o Reno e o Danúbio cessou. As cidades italianas entraram em uma rápida decadência. Os nobres alemães, que haviam se incorporado aos burgueses das cidades livres, empobreceram e se voltaram ao óbvio expediente de recuperar suas perdas através da pilhagem de seus súditos. $E$ veio a Guerra dos Camponeses, seus ferozes incidentes, sua cruel repressão e 0 desenvolvimento das seitas selvagens que desfiguraram e detiveram a Reforma alemã. A batalha das pirâmides, na qual Selim ganhou o sultanato do Egito para os turcos otomanos, trouxe perda e aflição para milhares de casas onde o evento permaneceu desconhecido. São fatos como estes que a interpretação econômica da história ilustra e expande.

Visto desta posição, o passado é preenchido com um novo significado. 0 ponto focal do interesse moderno é o quarto estado, a grande massa do povo. A história tem sido romance e tragédia. N ela lemos os brilhantes anais de poucos. As intrigas das cortes, o valor dos cavaleiros, os palácios e as pirâmides, 0 amor das damas, a canção dos menestréis, e os cantos das catedrais passam como um espetáculo, ou permanecem como música enquanto viramos as páginas. Mas a história também possui suas tragédias, que falam dos degradados trabalhadores rurais, labutando para que outros possam sonhar; a escravidão que tornou possível a glória da Grécia; a servidão que permitiu a grandeza de Roma - estas também demandam seus próprios anais. Estes fatores econômicos têm afetado a ascensão e queda das nações de maneira muito mais decisiva do que têm se mostrado, e sem eles a história não passa de um mero berloque. 
Mas não tentarei exaurir a lista sobre as concepções de história. Para um grande grupo de escritores, representados por Hume, o campo da escrita histórica é a arena onde os diferentes debates partidários contemporâneos se enfrentam. Whig luta contra Tory, e o partido do escritor sempre é vencedor, independentemente do custo para com a verdade. Estes historiadores partidários estão presentes inclusive na América. Para Carlyle, o adorador de heróis, a história é o palco onde poucos grandes homens encenam suas partes. Para Max Muller, a história é a exposição do crescimento das idéias religiosas. A história moralista nos ensina uma lição. Para o metafísico, a história é a realização de umas poucas leis importantes.

Nós claramente podemos escolher entre estas diferentes idéias. Se nós tentássemos ordená-las, descobriríamos que em cada era prevaleceu um diferente tipo de história. Para o selvagem, a história é o escalpo pintado, com a representação simbólica das vítimas de sua bravura; ou são as lendas dos heróis e deuses de sua raça - tentativas de explicar as origens das coisas. Daí o vasto corpo de mitologias, folclore e lendas, onde ciência, história e ficção estão misturadas, a imaginação e 0 julgamento inexoravelmente confundidos. Com o passar do tempo, chega o instinto artístico, e a escrita da história toma forma de uma "Ilíada" ou de um "N ibelungenlied" ("Canção dos Nibelungos"). Ainda assim, temos nestes escritos o reflexo daquela era crédula que acreditava na divindade de seus heróis e que escrevia sobre o que acreditava. As capacidades críticas e artísticas encontram sua expressão em Heródoto, o pai da história grega, e em Tucídides, 0 historiador grego ideal. Ambos escrevem sob 0 ponto de vista de uma civilização avançada e tentam apresentar um quadro real dos eventos, concatenando causas e efeitos. Mas Tucídites é um 
grego; para ele a literatura é uma arte, e a história é uma parte da literatura; não Ihe parece uma violação da verdade histórica fazer seus generais pronunciarem longas orações que Ihes foram impostas pelo historiador. Ademais, tanto homens primitivos quanto gregos acreditavam que suas próprias tribos ou Estados eram favorecidos pelos deuses: o resto da humanidade estava fora da história.

Para o historiador medieval, a história era os anais dos monastérios ou as crônicas da corte.

No século dezenove surgiu um novo método e um novo ideal para a história. A filosofia lhe preparou o caminho. Schelling ensinou a doutrina de "que o Estado não é realmente governado por leis criadas pelos homens, mas é uma parte da ordem moral do universo, controlado por forças cósmicas". Herder proclamou a doutrina do crescimento das instituições humanas. Ele via na história o desenvolvimento de certos germes; as religiões deveriam ser estudadas comparativamente, traçando suas origens desde a mais pura superstição até as concepções racionais de Deus. A linguagem também não era uma criação repentina, mas um crescimento, e deveria ser estudada como tal; isto também ocorre com as instituições políticas. Assim, ele abriu o caminho para o estudo da filologia comparada, da mitologia e da evolução política. Wolf, ao aplicar as sugestões de Herder à "Ilíada", não encontrou só um Homero, mas vários. Isto levou ao estudo crítico dos textos. Niebuhr aplicou este método de estudo aos historiadores romanos e descobriu suas incorreções A história de Lívio sobre a Roma primitiva virou lenda. Niebuhr tentou encontrar os fatos reais. Ele acreditava que isto era possível, mesmo que os romanos houvessem esquecido sua própria história, partindo das instituições contemporâneas em direção às suas antecessoras, assim como é possível 
para um biólogo descobrir a flor a partir do fruto. Ele traçaria as causas a partir dos efeitos. Em outras palavras, ele acreditava tão piamente no crescimento de uma instituição de acordo com leis fixas que achava possível a reconstrução do passado, atingindo os fatos reais mesmo a partir dos relatos incorretos dos escritores romanos.

Ainda que tenha levado seu método longe demais, ele é o fundador da escola histórica moderna. Ele tentou reconstruir a velha Roma a partir das autoridades originais que sobraram. Através da análise crítica e da interpretação, tentou usar estes textos para que a verdade enterrada pudesse vir à tona. À sua habilidade como antiquário ele uniu um grande conhecimento de política - pois $\mathrm{N}$ iebuhr era um estadista. Sua meta era unir o estudo crítico das fontes com a habilidade interpretativa do expert político, e esta tem sido a meta da nova escola de historiadores. Leopold von Ranke aplicou este método ao estudo da história moderna. Para ele, um documento do passado era muito mais valioso do que qualquer tradição sobre o próprio passado. 0 relato contemporâneo, usado de maneira correta, possuía mais autoridade do que qualquer relato de segunda mão. Sendo assim, ele pesquisou diligentemente nos empoeirados arquivos europeus, e o resultado de seu labor foi a reescrita da moderna história política e diplomática. Decretos, correspondências, crônicas, inscrições - estes são os materiais trabalhados por eles e seus discípulos. Relatar "as coisas como elas aconteceram" era o ideal de Ranke. Mas para ele a história também era a política passada.

Ainda que este resumo tenha sido apressado, acho que vocês podem entender que o estudo histórico da primeira metade do século dezenove refletia o pensamento daquele período. Este foi um tempo de agitação política e de investigação, como o 
nosso também é. Foi uma época devotada à ciência. Este estudo indutivo dos fenômenos, que produziu uma verdadeira revolução em nossos conhecimentos, foi aplicado à história. Resumindo, o estudo da história tornou-se político e científico.

Hoje, as questões mais importantes não são tanto as políticas, mas as econômicas. A era da máquina, do sistema fabril, é também a era da investigação social.

Sendo assim, não é estranho que o estudo histórico predominante seja o estudo das condições sociais passadas, a investigação da propriedade fundiária, da distribuição de riquezas e da base econômica geral da sociedade. Nossa conclusão, portanto, é que há grande verdade em todas estas concepções de história: a história é a literatura passada, a política passada, a religião passada, a economia passada.

Cada era tenta formar sua própria concepção do passado. Cada era reescreve a história do passado, com referência às condições próprias de seu tempo. Os historiadores aceitaram a doutrina de Herder. A sociedade cresce. Eles aceitaram a doutrina de Comte. A sociedade é um organismo. A história é a biografia da sociedade em todos os seus aspectos. Existe a história objetiva e a história subjetiva. A história objetiva diz respeito aos próprios eventos; a história subjetiva é a concepção que o homem tem destes eventos. Todo o modo e a maneira de olhar às coisas muda com o tempo, mas isto não significa que mudem os eventos reais de uma dada era; isto significa que muda a nossa compreensão destes fatos.

A história, subjetiva ou objetiva, está em eterna transformação; ela nunca está completa. Os séculos cada vez mais nos revelam o significado do passado. Compreendemos a história romana melhor do que Lívio ou Tácito, não só porque conhecemos melhor as fontes, mas também porque o significado real dos 
eventos se desenvolve com o tempo, dado que o hoje é tanto um produto do ontem, como o ontem só pode ser compreendido como é explicado hoje. A meta da história é, então, conhecer os elementos do presente através da compreensão do que nos restou do passado no próprio presente. Pois o presente nada mais é do que o passado em desenvolvimento, o passado sendo o presente não desenvolvido. É a mesma coisa que tentar explicar o ovo sem a compreensão da galinha, sua forma desenvolvida, e tentar explicar o passado sem a compreensão do presente. $\mathrm{O}$ antiquário tenta recuperar o passado nos termos do próprio passado; o historiador tenta mostrar o presente a si mesmo ao revelar suas origens no passado. A meta do antiquário é o passado morto; a meta do historiador é o presente vivo. Droysen transformou esta verdade em uma afirmação: "A História é o 'Conhece-te a ti mesmo' da humanidade - a autoconsciência dos homens."

Se aceitarem comigo a afirmação deste grande mestre da ciência histórica, o resto de nosso caminho fica claro. Se a história é, na verdade, a autoconsciência da humanidade, a "autoconsciência da era viva, adquirida a partir da compreensão do passado", todo o resto segue.

Em primeiro lugar, devemos reconhecer que todas as atividades humanas devem ser consideradas. Não somente esta é a única maneira através da qual podemos ter uma visão completa da sociedade, assim como nenhum departamento da vida social pode ser estudado isoladamente. A vida política e a vida econômica tocam, modificam e condicionam uma à outra. Mesmo a vida religiosa precisa ser estudada em conjunção com a vida política e econômica, e vice-versa. Assim, todos os tipos de história são essenciais - história como política, história como arte, história como economia, história como religião 
- todas são partes da tentativa da sociedade de se entender a partir da compreensão do passado.

Em segundo lugar, vemos que a história não está encerrada em um livro - não em muitos livros, pelo menos. A primeira lição que o estudante deve aprender é o descarte da concepção de que existem histórias definitivas. Isto é impossível. A história é tudo aquilo que restou do passado e que chegou ate nós, estudado com todo o poder crítico e interpretativo que só o presente pode trazer. De tempos em tempos os grandes mestres trazem suas investigações à fruição em livros. Eles servem, para nós, como o melhor resultado dos mais recentes esforços da sociedade em se autocompreender - mas eles não são as palavras finais. 0 material do historiador é tudo aquilo que sobrou de eras passadas - papéis, estradas, túmulos, costumes, línguas; monumentos, moedas, medalhas, nomes, inscrições, títulos, decretos; anais e crônicas; e, finalmente, as fontes secundárias, ou histórias na comum acepção do termo. Em qualquer lugar em que exista uma pedra lascada, uma ponta de lança, um pedaço de cerâmica, uma pirâmide, um retrato, um poema, um coliseu ou uma moeda, lá está a história.

\section{Diz Tayne:}

Qual é a sua primeira observação quando vira as rijas páginas de um fólio, as folhas amareladas de um manuscrito, um poema, um código de leis, uma declaração de fé? Isto, você diz, não foi criado sozinho. É como se fosse um molde, tal qual um fóssil, uma impressão como aquelas formas petrificadas de um animal que viveu e morreu. Sob o fóssil havia um animal, sob o documento havia um homem. Por que você estuda o fóssil senão pelo animal? Você só estuda o documento para poder conhecer o homem. 0 fóssil e o homem são coisas sem vida, valiosas somente no sentido que 
nos dizem algo sobre a experiência vivida. Devemos tentar alcançar esta experiência, tentar recriá-la.

$M$ as observe que quando um homem escreve uma narração do passado, ele o faz com todas as suas limitações quanto à possibilidade de testar 0 real valor de suas fontes e a sua capacidade de interpretálas. Ele faz uso de uma crônica? Primeiramente ele deve determinar se ela é genuína; depois, se ela é contemporânea aos acontecimentos ou se foi escrita em outra época; verificar que oportunidades o autor tinha de conhecer a verdade; quais eram seus traços pessoais; tentar estabelecer sua imparcialidade; se não, quais suas limitações e preconceitos?; por último vem a parte mais difícil - a interpretação do real significado dos eventos; as causas devem ser compreendidas, os resultados vistos. Assuntos locais devem ser descritos em relação aos assuntos mundiais - tudo deve ser contado com seleção, ênfase, perspectiva; com toda aquela compreensão e imaginação histórica que não julga o passado com os termos do presente, e nem lê nele as idéias do presente. Os historiadores devem, acima de tudo, ter uma paixão pela verdade. Estas são algumas das dificuldades da nossa ciência. Ademais, quando consideramos que cada homem é condicionado pela época em que vive e, portanto, escreve com todas as limitações e preconceitos que lhe são impostos, acho que podemos concordar que nenhum historiador possui a palavra final.

Um outro pensamento que segue como um corolário à nossa definição é que na história existem a unidade e a continuidade. Estritamente falando, não há nenhum gap entre a história antiga, a medieval e a moderna. O barão Bunsen data a história moderna aos tempos da migração de Abraão. Bluntschli a inicia com Frederico, o Grande. 
A verdade, como nos mostrou Freeman, é que a época de Péricles ou a era de Augusto possui mais coisas em comum com o período moderno do que os tempos de Alfredo ou Carlos M agno. Existe outro teste que não o da cronologia: o dos estágios de crescimento. No passado europeu, famílias evoluíram em estados, da vida rural à complexidade da vida urbana, do animismo ao monoteísmo, da mitologia à filosofia; e abriram caminho para povos primitivos que passaram pelos mesmos estágios e, por sua vez, abriram caminho para outras nações. Cada nação legou algo aos seus sucessores; nenhuma era se desvencilhou completamente do passado. Através de uma herança inconsciente, e de uma luta consciente em dar ao passado um lugar no presente, a história adquiriu continuidade. A afirmação de Freeman de que todo o mundo antigo fluiu a Roma e que todo o mundo moderno nasceu de Roma é tão verdadeira quanto impressionante. Em um sentido estrito, Roma nunca morreu. Vocês poderão encontrar a Cidade Eterna viva no kaiser e no czar, na língua dos povos latinos, nos códigos dos Estados europeus, nas águias de seus brasões, nas faculdades onde se lêem os clássicos, em milhares de instituições políticas.

Mesmo na jovem América Roma ainda vive. Quando o discurso inaugural passa para o Senado, e o presidente enumera as políticas que pretende levar a cabo, lá está Roma! Vocês poderão encontrá-la no código da Louisiana, nas porções francesas e espanholas da nossa história. Roma pode ser vista nos títulos, no governo e nas cerimônias da I greja Católica; pois quando morreu o César, seu cetro caiu nas mãos do novo pontifex maximus, o papa, e do novo Augusto, o sagrado imperador romano da I dade M édia, um império que continuou até aqueles tempos heróicos quando um novo imperator relembrou os dias de Júlio, e mandou as águias da 
França proclamarem que Napoleão era o novo rei dos reis.

Então é verdade o fato, que podemos presumir a priori, de que na história só existem divisões artificiais. A sociedade é um organismo em constante crescimento. A história é a autoconsciência deste organismo. As raízes do presente estão no passado. $\mathrm{N}$ ão há intervalos. M as não só isso é verdade como também que nenhum país pode ser estudado sem se levar em consideração todo o seu passado; assim como não devemos nunca limitar nossos estudos a um pequeno pedaço de terra, pois a história local só pode ser compreendida em relação com a mundial. Existe tanto unidade quanto continuidade. Para conhecer a história da Itália contemporânea, devemos conhecer a história da França contemporânea e da Alemanha contemporânea. Uma age na outra. As idéias e os costumes rejeitam os limites de uma nação. Todas estão inextricavelmente conectadas. $\mathrm{N}$ a história, portanto, existe unidade e continuidade. Cada época deve ser estudada sob a luz do passado; a história local deve ser estudada à luz da história mundial.

Acredito que já estejamos na posição de considerar a utilidade dos estudos históricos. Não vou me deter na dignidade da história sob o aspecto de autoconsciência da humanidade; nem no crescimento mental que advém do estudo da disciplina; nem na vastidão do campo; vocês já sabem tudo isso, e a sua importância vai aumentar consideravelmente se pensarem na história a partir deste ponto de vista. A história nos permite contemplar o nosso próprio tempo e lugar como uma parte do estupendo progresso das eras; ver 0 homem primitivo; reconhecer em nosso meio as imortais idéias da Grécia; encontrar a majestade e 0 poder de Roma ainda vivos em nossas instituições e leis, em nossas superstições e no nosso folclore; nos 
permite perceber a riqueza de nossa herança, a possibilidade de nossas vidas, a grandeza de nosso presente - estes são alguns dos inestimáveis serviços da história.

Mas devo concluir meus comentários com algumas palavras sobre a utilidade da história em fornecer um bom treinamento cívico. Sem dúvida, o civismo é a meta principal de nossas escolas públicas. Se não fosse assim, não existiria justificativa para sua existência. A importante utilidade da história para o alcance desta meta dificilmente precisa de argumentos.

A Alemanha tem sido preeminente na união entre o serviço público e os estudos históricos. 0 treinamento nos estudos históricos é essencial para o exercício de certos cargos governamentais. 0 expresidente Andrew D. White afirma que a eficiência do serviço público alemão deriva em grande medida do treinamento em história e do estudo da política. Em Paris existe a famosa Escola de Ciências Políticas, que prepara homens para o serviço público francês. $\mathrm{Na}$ década encerrada em 1887, alguns concursos demonstraram as vantagens deste treinamento. Dos sessenta candidatos nomeados para o Conselho de Estado, quarenta eram graduados por essa escola. Dos quarenta e dois nomeados para a inspeção das finanças, trinta e nove eram da escola; dezesseis dos dezessete nomeados para a corte de apelações; e vinte dos vinte e seis nomeados para o departamento de assuntos externos eram diplomados pela Escola de Ciências Políticas. Nos países europeus não só os funcionários públicos devem possuir treinamento em história; a lista dos maiores estadistas do continente revela vários nomes proeminentes da ciência histórica. Eu nem precisaria lembrá-los de grandes nomes como Niebuhr, cuja história de Roma deu um novo ímpeto à nossa ciência; Stein, o reconstrutor da Alemanha e projetista da 
"Monumenta Germanicae", aquela maravilhosa coleção de fontes para o estudo da Alemanha medieval. Leiam a lista dos grandes servidores públicos alemães e vocês encontrarão entre eles nomes como o de Gneist, a autoridade em história constitucional inglesa; Bluntschli, o hábil historiador político; Von Holst, o historiador de nosso próprio desenvolvimento político; Knies, Roscher e Wagner, os economistas; e muitos outros. Eu lhes mostrei a concepção histórica de Droysen. Mas Droysen não era um simples historiador; ele pertencia, juntamente com historiadores famosos como Treitschke, Mommsen e Von Sybel, àquele grupo que Lord Acton chama de "o grupo central de escritores e estadistas que viraram a maré que correu por seiscentos anos, e conquistaram as forças centrífugas que reinaram na Alemanha durante mais tempo do que os plebeus têm sentado em Westminster".

Inglaterra também não hesita em reconhecer 0 valor da união entre história e política, exemplificada em M acaulay, Dilke, M orley e Bryce, todos os quais foram importantes membros do Parlamento assim como historiadores brilhantes. $\mathrm{Na}$ França e na Itália estes exemplos podem ser facilmente multiplicados.

Quando nos viramos para a América e perguntamos quais casamentos foram celebrados entre a história e a política, deparamos-nos com 0 contrário. É verdade que o nosso país tentou recompensar alguns literatos: Motley, Irving, Bancroft e Lowell detiveram posições no serviço público, mas no campo da diplomacia. 0 Estado Ihes deu ajuda ao invés de ter se valido dela. Existe somente uma exceção a esta afirmação - George Bancroft. Na América, a arte de governar tem sido considerada algo nascido espontaneamente, fruto de nossas instituições republicanas. Demandar dos estadistas, que debatem tópicos tais como impostos, 
relações internacionais, imigração e problemas trabalhistas, uma relação científica com a história política ou econômica era se expor ao ridículo diante dos olhos do público. Eu afirmei anteriormente que o estágio tribal da sociedade demanda uma história tribal e uma política tribal. Quando uma sociedade está isolada, ela olha com desprezo para a história e as instituições do resto do mundo. Não estaríamos de todo errados se afirmássemos que este tipo de ponto de vista tem prevalecido em nosso país. Ultimamente os historiadores têm se voltado aos estudos comparativos sobre nossas instituições. As nossas práticas constitucionais, e seu contraste com sua teoria literária, têm sido o alvo de tais cientistas. Estrangeiros como Von Holst e Bryce nos mostraram um espelho de nossa vida política à luz da vida política de outros povos. M as ainda não têm atraído a atenção de nossos homens públicos. Leiam a lista do Senado e da Câmara de Deputados, dos ministérios e da diplomacia - para não dizer nada sobre os governos estaduais - e onde estão os nomes famosos da história e da política? É idiotice exprimir satisfação com esta situação e zombar dos literatos. Parece-me, assim, que estamos chegando a um ponto crucial na história de nosso país.

Em um de meus comentários iniciais citei Thorold Rogers para demonstrar como a conquista turca do Egito trouxe a ruína para Bruxelas e Antuérpia. Se à época isto era verdade, quando os laços comerciais eram infinitamente menos complexos, o que dizer dos dias de hoje - quando nossa vida está profundamente ligada aos acontecimentos mundiais? Até a atualidade, a América tem se mantido distante dos assuntos do Velho M undo. Mas uma das mais profundas lições que podemos tirar da história é que as relações políticas, em uma civilização avançada, estão inextricavelmente conectadas às relações 
econômicas. 0 nosso isolamento político e comercial parece estar dando sinais de relaxamento. A reciprocidade é uma palavra que tem encontrado eco em diferentes segmentos da sociedade. Uma vez lançados ao mar dos interesses econômicos mundiais, nós logo desenvolveremos interesses políticos. Nossas disputas pesqueiras fornecem um exemplo disto; nossos interesses em Samoa, outro; nossas relações com o Congo, um terceiro. M as a mais importante destas talvez seja a nossa relação com a América do Sul em conjunto com a nossa Doutrina Monroe. $O$ direito que um governo estrangeiro tem de interferir em um outro país para garantir seus investimentos, caso eles estejam a perigo, é uma máxima estabelecida pelo direito internacional. Como apontou o professor $\mathrm{H}$. B. Adams, os Estados sul-americanos mantêm profundas relações comerciais com a Europa, mas também são propensos a revoluções. Suponhamos que a Inglaterra, para garantir os direitos de seus investidores, intervenha em algum país sulamericano. Deveriam os Estados Unidos abandonar a interpretação popular da Doutrina Monroe ou desistir de sua política de não-interferência nos assuntos políticos do mundo exterior? Ou, supondo que os acionistas de N ova York estejam em perigo de perder seus ganhos por causa de revoluções na América do Sul - e a nossa tendência a estreitar as conexões com os assuntos sul-americanos tornam este cenário bastante provável -, nosso governo deveria ficar tranqüilo enquanto os interesses de seus cidadãos são sacrificados? Peguem outro caso, 0 protetorado do proposto canal interoceânico. A Inglaterra não vai se contentar em permitir seu controle somente por nossas mãos. Será que os Estados Unidos formarão uma aliança com a Inglaterra com o intuito de lograr tal proteção? Questões como estas indicam que estamos sendo 
impelidos em direção às relações políticas européias, e que uma nova habilidade política é demandada, uma que compreenderá perfeitamente a história européia e suas relações com o presente, que depende da história.

Novamente, considerem o problema do socialismo, trazido a estas plagas pelos imigrantes europeus. Nós nunca poderemos lidar corretamente com este problema até que tenhamos a compreensão das condições históricas de onde emergiu. Assim, não só encontramos a Europa fora de nossas fronteiras, mas também em nosso próprio meio. 0 problema da imigração fornece muitos exemplos para a necessidade dos estudos históricos. Considerem como o nosso vasto domínio ocidental foi colonizado. Luís XVI devasta o Palatinado, e logo centenas de seus habitantes estão derrubando as florestas da Pensilvânia. 0 bispo de Salzburgo persegue seus súditos protestantes e os bosques da Geórgia tremem ao som dos rifles teutônicos. Os presbiterianos são oprimidos na Irlanda e as fogueiras dos pioneiros brilham no Kentucky e no Tennessee. Estes foram a guarda avançada do poderoso exército que penetrou em nosso meio desde então. Cada mudança econômica, cada mudança política, cada recrutamento militar, cada agitação socialista na Europa nos mandou grupos de colonos que se assentaram nas nossas planícies para formar novas comunidades autogovernadas ou entraram na vida de nossas grandes cidades. Estes homens vieram até nós como produtos históricos, eles não trouxeram somente força e vigor, dinheiro e habilidades manuais, eles trouxeram costumes e ideais profundamente enraizados. Eles são importantes fatores políticos e econômicos na vida da nação. N osso destino se entrelaça com os deles; como poderemos entender a história americana sem entender a história européia? A história do 
povoamento da América ainda não foi contada. Nós não nos entendemos.

Um dos campos mais frutíferos de pesquisa em nosso país tem sido o estudo dos processos de crescimento de nossas instituições, nacionais e locais. A cidade e o condado, os germes de nossas instituições políticas têm sido traçados de volta às raízes teutônicas. A afirmação de Gladstone de que "a Constituição americana é o mais maravilhoso trabalho já criado pela razão humana em um dado tempo" tem sido desmentida, porque a Constituição foi, com todos os poderes construtivos dos pais da pátria, ainda um crescimento; e nossa história somente pode ser entendida como um crescimento da história européia, nas condições do Novo M undo. Diz o Dr. H. B. Adams:

A história local americana deveria ser estudada como uma contribuição à história nacional. Este país ainda está para ser visto e pesquisado como um organismo de crescimento histórico, desenvolvido a partir de germes minúsculos e do próprio protoplasma da vida estatal. E um dia este país será estudado em suas relações internacionais, como uma parte orgânica de um organismo maior agora vagamente chamado de Estado-M undo, mas certamente desenvolvendo-se através das operações das forças econômicas, legais, sociais e científicas como a União Americana, os impérios da Alemanha e da Inglaterra, que estão evoluindo em formas mais avançadas [...]. A consciência local deve ser expandida em um sentido mais amplo de seu valor histórico e dignidade. Nós devemos compreender as relações cosmopolitas da moderna vida local e seu benéfico poder conservador nestes dias de crescente centralização.

Se fosse preciso mais algum argumento para demonstrar que uma boa cidadania demanda 0 cuidadoso estudo da história, ele está nos exemplos e 
lições que a história de outros povos nos disponibiliza. É profundamente verdadeiro que cada povo faz sua própria história de acordo com seu passado. É verdade que uma peça legislativa puramente artificial, sem relação com as condições passadas e presentes, é algo de vida curta. Ainda assim, devemos lembrar que foi a história que nos ensinou tal verdade, e que existe, dentro dos limites possíveis à ação construtiva do Estado, um grande escopo para o uso da experiência dos povos estrangeiros.

Eu tentei oferecer, assim, estas considerações: a História não deve ser tomada em nenhum sentido estrito. Ela é mais do que a literatura passada, mais do que a política passada, mais do que a economia passada. Ela é a autoconsciência da humanidade - a tentativa humana de se compreender a partir do estudo do passado. Sendo assim, ela não está confinada aos livros; o objeto é que deve ser estudado, não os livros. A História possui uma unidade e uma continuidade; o presente precisa do passado para ser explicado; e a história local deve ser lida como uma parte da história mundial. 0 estudo possui utilidade como uma disciplina mental, e como uma expansão de nossas ideais sobre a dignidade do presente. Mas talvez sua mais prática utilidade para nós, professores de escolas públicas, seja seu serviço em alimentar uma boa cidadania.

Os ideais apresentados podem parecer desencorajadores. Mesmo para aquele que devota sua vida ao estudo da história, a concepção ideal é impossível de ser alcançada. Ele deve selecionar um campo e ser seu absoluto mestre; de resto, ele deve buscar 0 auxílio de outros cujas vidas têm sido devotadas, em um espírito inquestionavelmente científico, ao estudo de campos especiais. 0 professor da escola pública deve fazer o melhor uso das bibliotecas à sua disposição. Nós, professores, 
devemos usar todos os recursos que podemos obter e não prender nossa fé a um único livro; nós devemos fazer uma história viva em vez de permitir que ela pareça uma mera literatura, uma mera narração de eventos que poderiam muito bem ter acontecido na Lua. Devemos ensinar a história completa de poucos países e não a história superficial de muitos. A popularização do conhecimento científico é um dos melhores feitos desta era da imprensa. É típica daquele impulso social que levou os homens da universidade a levar os frutos de seus estudos ao povo. Na Inglaterra, este impulso social levou ao que é conhecido como o movimento de extensão universitária. Os homens das universidades deixaram seus claustros e foram viver entre as classes trabalhadoras, com o intuito de lhes trazer uma nova vida intelectual. Chautauqua, em nosso próprio país, tem começado a ir além do período de trabalho superficial para uma real união entre o científico e o popular. Em sua escola de verão eles oferecem cursos sobre a história americana. Nossa própria universidade estadual realiza cursos de extensão em tópicos diversos. Acredito que este movimento em direção à popularização do conhecimento histórico e científico vai realizar uma verdadeira revolução em nossas cidadelas e aldeias assim como em nossas grandes cidades.

O professor é chamado a fazer um trabalho que vai muito além da simples instrução escolar. Ele é chamado a ser 0 apóstolo da alta cultura na comunidade em que vive. Com uma boa escola ou biblioteca municipal - tal coisa está agora ao alcance de cada povoado propriamente estimulado à sua aquisição - e com um professor devotado e enérgico, dedicado a fomentar o estudo da história, da política e da economia, nós teríamos uma regeneração intelectual do Estado. 0 estudo histórico tem por fim deixar a comunidade ver-se sob a luz do passado, 
dando-Ihe novos pensamentos e sentimentos, novas aspirações e energias. Pensamentos e sentimentos fluem em ações. Aqui está o poder do motivo que jaz por trás das instituições. Este é um dos caminhos para criar a boa política; aqui nós podemos tocar 0 "período e o corpo do tempo, sua forma e pressão". Vocês têm pensado em coisas melhores ou têm uma reforma para alcançar? "Ponha-os no ar", diz o grande professor. As idéias regem e sempre regerão. Nós devemos fazer a extensão universitária ser sentida como foi na Alemanha. Evitem como um pecado imperdoável qualquer unilateralidade, qualquer partidarismo, qualquer tratamento parcial da história. Não interpretem erroneamente 0 passado sob a luz do presente. 0 homem que entra no templo da história deve responder devotadamente àquela invocação da igreja, Sursum corda, corações ao alto. Nenhum olhar para a história como sendo um conto frívolo, um compêndio de anedotas; nenhuma devoção servil ao manual; nenhuma negligência com os mortos que não podem mais falar serão permitidos neste santuário. "A História", diz Droysen, "não é a verdade e a luz; mas uma luta para isto, um sermão sobre isto, uma consagração a isto".

TURNER, Frederick Jackson. The Significance of History. Translation and Introduction Arthur Lima de Ávila. História, São Paulo, v.24, n.1, p.??-??, 2005.

ABSTRACT: Frederick Jackson Turner (1861-1932) was one of the most important American historians of the twentieth-century. Through his influence in the academy, the study of the so-called "problemoriented-history" was institutionalized, on the basis 
that the discipline should provide a greater understanding of the present through the analysis of the past. Defender of the presentist character of History and of a bland relativism, Turner established some of the postulates that would become standards in the universities of the United States, such as the study of the "invisible forces" that shape and determine the historical process and of the great mass of anonymous human beings that helped to build democracy on American soil.

KEYWORDS: Frederick Jackson Turner; American historiography; presentism.

\section{NOTAS}

1 Texto publicado originalmente no Wisconsin Journal of Education (out-nov, 1891). Para a tradução foi utilizada a versão presente em FARAGHER, John (org.). Rereading Frederick Jackson Turner. New Haven: Yale University Press, 1998, p.1130 .

Tradução e apresentação Arthur Avila de Lima.

${ }^{2}$ Doutorando no Programa de Pós-Graduação em História do Instituto de Filosofia e Ciências Humanas da Universidade Federal do Rio Grande do Sul - UFRGS - Porto Alegre, CEP 90040-060. Trabalho realizado com o auxílio do CNPq. e-mail: arthuravila@gmail.com.

${ }^{3}$ BILLINGTON, Ray Allen. Frederick Jackson Turner: historian, scholar, teacher. New York: University of Oxford Press, 1973. p.416.

4 MOURA, Gerson. História de uma História: rumos da historiografia norte-americana do século XX. São Paulo: Edusp, 1995, p.15-16.

${ }^{5}$ NOVICK, Peter. That Noble Dream: the "Objectivity Question" and the American historical profession. 4.ed. New York: University of Cambridge Press, 1990, p.87-88.

${ }^{6}$ TURNER, Frederick Jackson. The Significance of the Frontier in American History. In: The Frontier in American History. New 
York: Dove, 1996. Este texto, junto com outros três, foi recentemente traduzido para o português pelo professor Paulo Knauss, da Universidade Federal Fluminense. Ver KNAUSS, Paulo (org.). O Oeste Americano: quatro ensaios de história americana. Rio de Janeiro: EdUFF, 2004.

7 Estes dois ensaios também estão na supracitada coletânea organizada pelo professor Knauss.

8 Turner nunca sistematizou a sua frontier thesis em um único livro. Durante toda a sua vida, ele a divulgou em ensaios e artigos, em geral derivados de palestras e exposições orais. Os mais importantes foram compilados em 1920, para a coletânea The Frontier in American History ("A Fronteira na História Americana"). O historiador só lançou uma obra completa em vida, "The Rise of the New West" ("O Surgimento do Novo Oeste”), em 1906. Mais dois livros foram lançados postumamente, "The Signifcance of Sections in American History" ("O Significado das Seções na História Americana”), em janeiro de 1933, e "The United States: the Nation and its Sections" ("Os Estados Unidos: a Nação e suas Seções”), em janeiro de 1935 .

${ }^{9}$ BILLINGTON, Ray Allen. Frederick Jackson Turner. Op. cit. p.233-258, 308-336.

${ }^{10}$ Idem, p.489-490.

${ }^{11}$ SLOTKIN, Richard. The Gunfighter Nation: the Myth of the Frontier in Twentieth-Century America. Norman: University of Oklahoma Press, 1992. p.33. Isto se refletiu na utilização da frontier thesis por uma diversidade de grupos sociais, desde políticos reformistas e empresários conservadores até defensores do expansionismo norte-americano em direção a América Latina e ao Extremo Oriente. Vale mencionar que três presidentes da República, Theodore Roosevelt (1901-1909), Woodrow Wilson (1914-1921) e Herbert Hoover (1929-1933), eram admiradores da obra de Turner e chegaram a usar sua obra para embasar suas algumas de suas políticas, especialmente nos caso de Wilson. O presidente havia sido colega de Turner em Johns Hopkins e chegou a declarar-se mais turneriano que o próprio Turner. Sobre estes, e outros usos da teoria turneriana, ver WROBEL, David M. The End of American Exceptionalism: frontier anxiety from the Old West to the New Deal. 2.ed. Lawrence: University of Kansas Press, 1993. ${ }^{12}$ Ver as seguintes coletâneas: BILLINGTON, Ray Allen (org.). The Frontier Thesis: valid interpretation of American History? 
New York: Holt, Hineheart and Winston, 1966. \& HOFSTADTER, Richard \&LIPSET, Seymour Martin (org.). Turner and the Sociology of the Frontier. New York: Basic Books, 1968.

${ }^{13}$ Ver KLEIN, Kerwin Lee. Frontiers of Historical Imagination: narrating the European conquest of Native America (18901990). 3.ed. Berkeley: University of California Press, 1999. p.37-47.

${ }^{14}$ Para um apanhado geral das posições da New Western History ver: LIMERICK, Patricia Nelson Limerick; MYLNER II, Clyde A; RANKIN, Charles E. Trails: toward a New Western History. Lawrence: University Press of Kansas, 1993.

15 FARAGHER, John Mack. The Frontier Trail: Rethinking Turner and Reimagining the American West. In: American Historical Review. American Historical Association: Washington, v.98, n.1, p.106-119. February, 1993

${ }^{16}$ Patricia Limerick e William Cronon, dois dos maiores críticos contemporâneos de Turner, escreveram dois artigos "reabilitando" o pai da frontier thesis, reconhecendo nele o pioneiro da História Social nos Estados Unidos. CRONON, William. Turner's First Stand: the significance of significance in American History. In: ETULAIN, Richard (org.). Writing Western History: essays on major western historians. University of Nevada Press, 1993. p.73-102. LIMERICK, Patricia Nelson. Turnerians All: the dreams of a helpful history in an intelligible world. In: Something in the Soil: field testing the New Western History. New York: W. W. Norton, 2001. p.141-166.

17 TURNER, Frederick Jackson. Letter to Constance Skinner, March 15th, 1922. In: BILLINGTON, Ray Allen. The Genesis of the Frontier Thesis: a study in historical creativity. San Marino: Huntington, 1971, p.205.

${ }^{18}$ BILLINGTON, Ray Allen. Frederick Jackson Turner. Op. cit., p. 474 .

Artigo recebido em 05/2006. Aprovado em 06/2006. 